\title{
Climate Change Capacity Discovery: \\ Current Activities and Future Priorities at Land-grant Universities in the Northeast
}

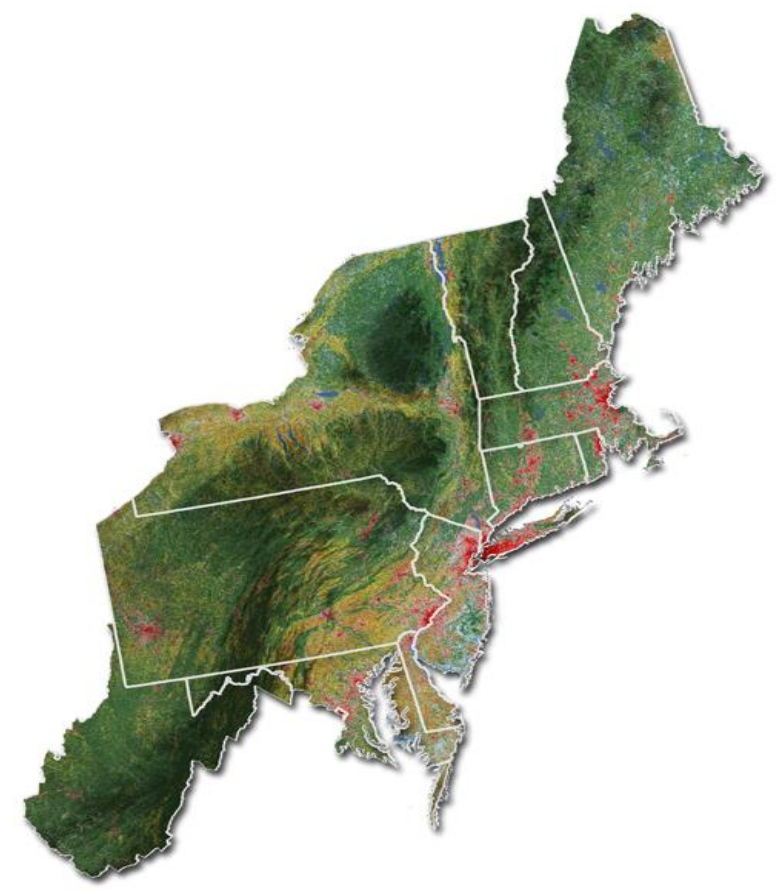

Daniel Tobin, Ph.D., The Pennsylvania State University

Rama Radhakrishna, Ph.D., The Pennsylvania State University

Allison Chatrchyan, Ph.D., Cornell University

Joana Chan, Ph.D., Cornell University

Shorna Allred, Ph.D., Cornell University

USDA Northeast Climate Hub in partnership with:

University of Connecticut

Cornell University

University of Delaware

Delaware State University

University of District of Columbia

University of Maine

University of Maryland

University of Maryland Eastern Shore

University of Massachusetts

University of New Hampshire

The Pennsylvania State University

University of Rhode Island

Rutgers University

University of Vermont

West Virginia University

West Virginia State University 


\section{Table of Contents}

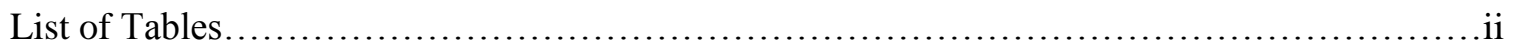

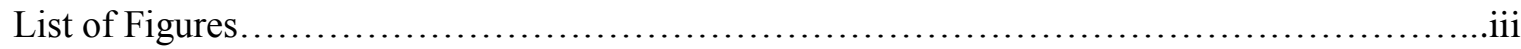

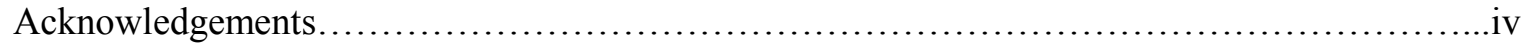

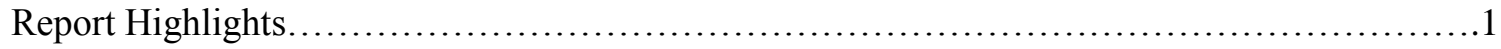

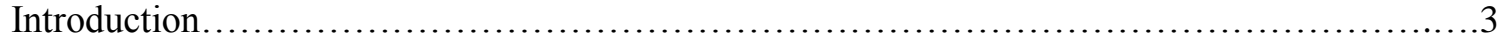

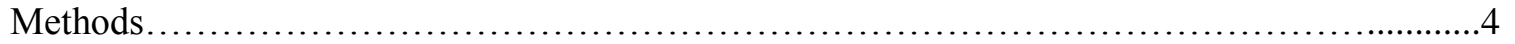

Glossary of Terms...............................................................

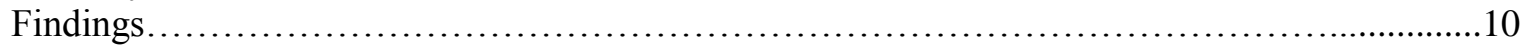

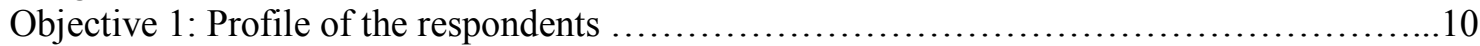

Objective 2: Content of current climate change activities................................ 13

Objective 3: Preferred delivery methods............................................ 19

Objective 4: Future priorities and willingness to participate in climate change activities.......20

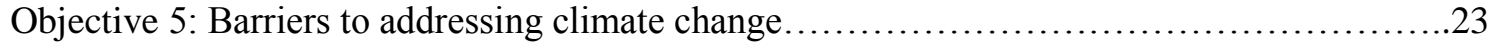

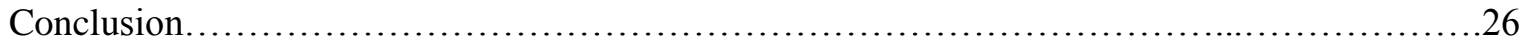

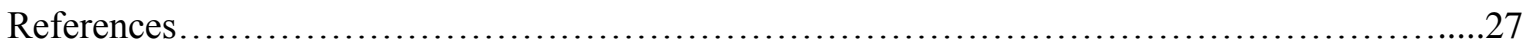

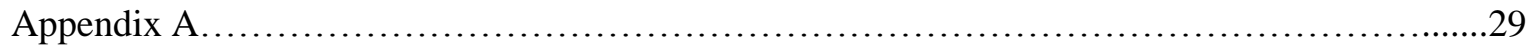




\section{List of Tables}

Main Report

Table 1. Colleges and Extension programmatic areas surveyed at land-grant universities........6

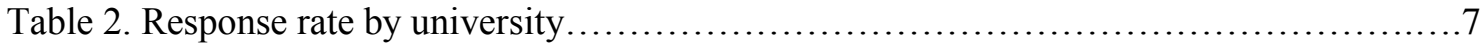

Table 3. Profile of respondents with at least $1 \%$ of their time dedicated to climate change

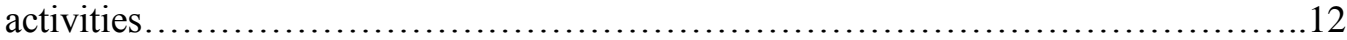

Table 4. Geographical focus of climate change activities.................................

Table 5. Percentage of respondents conducting research and Extension activities on specific climate change impact content areas................................... 14

Table 6. Percentage of respondents conducting research and Extension activities on specific climate adaptation content areas........................................ 15

Table 7. Percentage of respondents conducting research and Extension activities on specific climate mitigation content areas........................................ 15

Table 8. Number of types of resources on different climate topics........................... 18

Table 9. Rankings of future priorities of research faculty, Extension faculty, and Extension educators for climate change activities at land-grant universities........21

Appendix A

Table 1. Frequency and percentage of respondents working on climate change impact activities

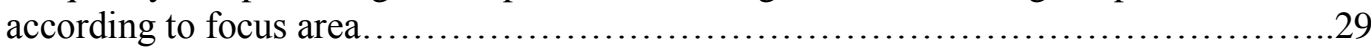

Table 2. Frequency and percentage of respondents working on climate adaptation activities according to focus area.......................................................... 30

Table 3. Frequency and percentage of respondents working on climate change mitigation activities according to focus area... ................................................... 


\section{List of Figures}

\section{Main Report}

Figure 1. Professional activities on climate change in the past year......................... 16

Figure 2. Usefulness of delivery methods to disseminate climate change information and Change climate change practices or behaviors..................................19

Figure 3. Willingness to participate in future climate change activities among research and Extension respondents.................................................... 22

Figure 4. Mean scores of information availability barriers to addressing climate change among research and Extension respondents....

Figure 5. Mean scores of workplace barriers to addressing climate change among research and Extension respondents

Figure 6. Mean scores of target audience barriers to addressing climate change among research and Extension respondents.... 


\section{Acknowledgements}

Funding from the USDA Northeast Climate Hub helped make the completion of this report possible. Without the support and assistance of the land-grant university partners in the Northeast, this report could not have come to fruition. The authors extend their sincere appreciation to the various deans who encouraged their faculty members and Extension personnel to complete the survey, as well as the staff assistants, project coordinators, and graduate students who helped distribute pre-announcements and compile other information. Kaila Thorn, graduate assistant at Penn State, merits acknowledgement for her

help in formatting and helping to prepare this report. Gary Thompson, Associate Dean for Research and Graduate Education in the College of Agricultural Sciences at Penn State, as well as Howard Skinner and Erin Lane of the USDA Northeast Climate Hub leadership team, all provided essential support for this project. Bill Hubbard and Daniel Geller from the University of Georgia also deserve our gratitude for assisting with the pilot test. 


\section{Report Highlights}

This report details the findings from the Capacity Discovery project, an online survey implemented in spring 2015 that documented the current and future capacity of land-grant universities in the Northeast to address climate change research and Extension work in the agriculture, natural resources, and forestry sectors. Highlights of the findings include:

- Resource and land management, land use and natural disaster planning, and Integrated Pest Management (IPM) are the most common climate change adaptation issues receiving attention from research and Extension in the region.

- The climate change mitigation issues that respondents most commonly reported working on were related to farm management and socioeconomic factors.

- Respondents were more likely to participate in trainings and workshops on climate change than they were to lead these trainings.

- Those who teach include climate change concepts more often in undergraduate courses than in graduate courses.

- The most common resources on climate change being developed by land-grant universities are newsletters, bulletins, factsheets, guidelines, datasets and models. These resources primarily focus on issues related to agriculture, water, land use, and ecosystems.

- Respondents perceived field tours, videos, and websites as the most helpful ways to disseminate information on climate change. While field tours and workshops were identified as the most useful delivery mechanisms to change practices or behaviors, they were not the most common methods that respondents used to deliver information.

- Research faculty, Extension faculty, and Extension educators identify similar future priorities for climate change work. Top priorities include training Extension educators on climate change, developing decision-support tools and websites, conducting cost-benefit analyses, and better understanding land managers' attitudes and needs. 
- For future activities, respondents are most interested in collaborating on regional research and programming initiatives, attending workshops and conferences, and developing and implementing educational programs.

- The primary barriers identified by respondents related to their conducting climate change work were the lack of climate change options adapted to local conditions, attitudes of target audiences, and the lack of time and funding.

Collectively, these findings provide an overview of the current and future capacity of land-grant universities in the Northeast to address climate change and point to key next steps for the USDA Northeast Climate Hub. Hub activities must focus on adapting climate information to local conditions and improving communication mechanisms with farmers, foresters, and other managers of natural resources to encourage adaptation and mitigation actions. The findings also suggest that potential exists for building networks and collaborations among researchers and Extension within universities as well as across the Northeast. 


\section{Introduction}

The USDA Climate Hubs were established in February 2014 to deliver science-based information relevant to specific geographical regions in order to facilitate climate change adaptation and mitigation among farmers, foresters, and other land managers. The Northeast Climate Hub, one among seven hubs nationally, is a consortium of three USDA agencies (Forestry Service, Agricultural Research Service, and Natural Resource Conservation Service) and 16 land-grant universities. To identify research and programmatic priorities, the Northeast Climate Hub is conducting a comprehensive needs assessment, which is considering the perspectives of policymakers, researchers and Extension professionals, and land managers. This report documents the findings from the Capacity Discovery survey, which assessed the current activities and future priorities of research and Extension regarding climate change and the agricultural, forestry, and natural resource sectors at the 16 land-grant universities in the Northeast.

Identifying current and future climate change work at land-grant universities is important to build regional collaborations, discover existing tools and technologies, and determine future initiatives. In addition, capturing the activities and priorities among land-grant universities provides an important basis of comparison with those of farmers, foresters, and other land managers and state policymakers. Guided by these goals, the purpose of the Capacity Discovery was to assess the current and future capacity of land-grant universities in the Northeastern U.S. to conduct research and Extension activities related to climate change in the agriculture, natural resource, and forestry sectors. Specifically, the objectives of the survey were to:

1) Describe the profile of respondents,

2) Discover current research and Extension activities being conducted,

3) Identify effective delivery methods to disseminate climate change research to farmers, foresters, and other land managers,

4) Ascertain the needs that respondents believe are most necessary to address in the future, and

5) Determine barriers respondents experience in conducting climate-related activities. 


\section{Methods}

To assess the current activities and future priorities being conducted at Northeastern land-grant universities, the sampling frame consisted of all faculty across the 16 land-grant universities who had appointments in colleges of agriculture, as well as all Extension specialists and educators who worked in programmatic areas related to agriculture, natural resources, or forestry at the university or in regional or county Extension offices. Although the organizational structures of the universities varied, care was taken to identify the colleges and programmatic areas at each university housing relevant disciplines. Table 1 describes the colleges and Extension program areas that were selected from each university to survey. Although not all individuals in these colleges and programmatic areas conducted activities related to climate change, a decision was made to construct a more inclusive frame so that respondents could selfidentify whether and how their work intersects with climate change. Given that the frame only includes specific colleges and programmatic areas within land-grant universities, the findings should be interpreted carefully; the findings do not provide a comprehensive representation of all climate change activities occurring within these universities. In total, 1,211 of 3,757 research participants completed the survey for a response rate of $32.2 \%$. Table 2 presents the response rates for each university.

To document current activities and future priorities, an online survey was developed using Qualtrics. Respondents were asked to respond to a series of semi-closed ended questions asking about the disciplinary areas of their climate change work, their current activities, the usefulness of various delivery methods, future priorities for climate change works at land-grant universities, barriers to achieve those future barriers, and demographic information. To enhance validity and reliability, the survey was reviewed by a panel of experts, field tested, and pilot tested. Data collection occurred during a six-week period in April - May 2015 and was guided by The Tailored Design Method (Dillman, Smyth, \& Christian, 2009). To analyze the data, only those respondents who had at least $1 \%$ of their time dedicated to climate change were considered. Of the 1,211 respondents, 554 (45.7\%) met this criterion; 263 respondents $(21.5 \%)$ reported that none of their time was dedicated to climate change and another 394 
respondents $(32.5 \%)$ did not indicate whether or how much of their time was spent on climate change.

Descriptive statistics were used to analyze the data. 
Table 1. Colleges and Extension programmatic areas surveyed at land-grant universities.

\begin{tabular}{|c|c|c|}
\hline University & College(s) & Extension program areas \\
\hline $\begin{array}{l}\text { University of } \\
\text { Connecticut (UConn) }\end{array}$ & $\begin{array}{c}\text { College of Agriculture, Health, and } \\
\text { Natural Resources }\end{array}$ & $\begin{array}{c}\text { Agriculture \& Food Systems; Land Use \& } \\
\text { Water; CT Green Industry }\end{array}$ \\
\hline Cornell & $\begin{array}{c}\text { College of Agriculture and Life } \\
\text { Sciences }\end{array}$ & $\begin{array}{c}\text { Agriculture \& Food Systems, Environment \& } \\
\text { Natural Resources, Gardening; Energy \& } \\
\text { Climate }\end{array}$ \\
\hline $\begin{array}{l}\text { University of Delaware } \\
\text { (UD) }\end{array}$ & $\begin{array}{c}\text { College of Agriculture and Natural } \\
\text { Resources }\end{array}$ & $\begin{array}{l}\text { Agriculture \& Natural Resources; Lawn \& } \\
\text { Garden }\end{array}$ \\
\hline $\begin{array}{l}\text { Delaware State } \\
\text { University (DSU) }\end{array}$ & $\begin{array}{c}\text { College of Agriculture \& Related } \\
\text { Sciences }\end{array}$ & Agriculture \& Natural Resources \\
\hline $\begin{array}{l}\text { University of DC } \\
\text { (UDC) }\end{array}$ & $\begin{array}{c}\text { College of Agriculture, Urban } \\
\text { Sustainability, \& Environmental } \\
\text { Sciences (minus Health Education and } \\
\text { Nursing) }\end{array}$ & $\begin{array}{c}\text { Center for Urban Agriculture \& Gardening } \\
\text { Education; Center for Sustainable } \\
\text { Development; Water Resources Research } \\
\text { Institute }\end{array}$ \\
\hline $\begin{array}{l}\text { University of Maine } \\
\text { (UM) }\end{array}$ & $\begin{array}{l}\text { College of Natural Resources, } \\
\text { Forestry, and Agriculture }\end{array}$ & $\begin{array}{c}\text { Agriculture; Garden \& Yard; Natural } \\
\text { Resources; Insect Pests, Ticks \& Plant } \\
\text { Diseases; Pesticide Safety }\end{array}$ \\
\hline $\begin{array}{l}\text { University of Maryland } \\
\text { (UMD) }\end{array}$ & $\begin{array}{c}\text { College of Agriculture and Natural } \\
\text { Resources }\end{array}$ & $\begin{array}{c}\text { Agriculture; Environment \& Natural } \\
\text { Resources; Home Gardening; Water and } \\
\text { Chesapeake Bay }\end{array}$ \\
\hline $\begin{array}{l}\text { University of Maryland } \\
\text { Eastern Shore (UMES) }\end{array}$ & $\begin{array}{c}\text { School of Agriculture and Natural } \\
\text { Resources }\end{array}$ & $\begin{array}{c}\text { Alternative \& Small Scale Agriculture, Small } \\
\text { Farm Outreach, Small Ruminant Production \& } \\
\text { Management }\end{array}$ \\
\hline $\begin{array}{l}\text { University of } \\
\text { Massachusetts (UMass) }\end{array}$ & $\begin{array}{l}\text { Stockbridge School of Agriculture, } \\
\text { Environmental Conservation, Food } \\
\text { Science, Microbiology, and } \\
\text { Veterinary and Animal Sciences } \\
\text { within College of Natural Sciences }\end{array}$ & $\begin{array}{l}\text { Agriculture \& Commercial Horticulture; } \\
\text { Environmental \& Water Conservation }\end{array}$ \\
\hline $\begin{array}{l}\text { University of New } \\
\text { Hampshire (UMass) }\end{array}$ & $\begin{array}{c}\text { College of Life Sciences and } \\
\text { Agriculture }\end{array}$ & $\begin{array}{c}\text { Agriculture; Gardens \& Landscapes; Natural } \\
\text { Resources }\end{array}$ \\
\hline Penn State (PSU) & College of Agricultural Sciences & Animals; Plants \& Pests; Natural Resources \\
\hline University of Rhode & College of Environment and Life & Sustainable Energy, Climate Change, \& the \\
\hline $\begin{array}{l}\text { Island (URI) } \\
\text { Rutgers University }\end{array}$ & $\begin{array}{c}\text { Sciences } \\
\text { School of Environmental and } \\
\text { Biological Sciences }\end{array}$ & $\begin{array}{l}\text { Environment; Food Production \& Sustainability } \\
\text { Environment \& Natural Resources, Fishers \& } \\
\text { Aquaculture; Home, Lawn \& Garden }\end{array}$ \\
\hline $\begin{array}{l}\text { University of Vermont } \\
\text { (UVM) }\end{array}$ & $\begin{array}{c}\text { College of Agriculture and Life } \\
\text { Sciences; Rubenstein School of } \\
\text { Environment and Natural Resources }\end{array}$ & $\begin{array}{l}\text { Agriculture; Environment \&Natural Resources; } \\
\text { Yard \& Gardening }\end{array}$ \\
\hline $\begin{array}{l}\text { West Virginia } \\
\text { University (WVU) }\end{array}$ & $\begin{array}{l}\text { Davis College of Agriculture, Natural } \\
\text { Resources, and Design }\end{array}$ & $\begin{array}{l}\text { Agriculture; Environment \& Natural } \\
\text { Resources; Lawn \& Garden }\end{array}$ \\
\hline $\begin{array}{l}\text { West Virginia (WVSU) } \\
\text { State University }\end{array}$ & $\begin{array}{l}\text { Agricultural and Environmental } \\
\text { Research Station }\end{array}$ & Agriculture \& Natural Resources \\
\hline
\end{tabular}


Table 2. Response rate by university

\begin{tabular}{lcc}
\hline University & N & Response Rate (\%) \\
\hline UConn & 74 of 202 & 30.3 \\
Cornell & 311 of 931 & 33.4 \\
UD & 49 of 184 & 26.6 \\
DSU & 9 of 22 & 40.9 \\
UDC & 5 of 24 & 20.8 \\
UM & 62 of 180 & 34.4 \\
UMD & 75 of 233 & 32.2 \\
UMES & 8 of 30 & 26.7 \\
UMass & 62 of 261 & 23.8 \\
UNH & 85 of 186 & 45.7 \\
PSU & 180 of 403 & 44.6 \\
URI & 51 of 218 & 23.4 \\
Rutgers & 88 of 267 & 32.9 \\
UVM & 79 of 396 & 19.9 \\
WVU & 61 of 201 & 30.3 \\
WVSU & 7 of 14 & 50.0 \\
\hline
\end{tabular}

\section{Glossary of terms}

The following definitions should be used as a reference when interpreting the data. For the purposes of analysis, some data were aggregated to facilitate analysis and interpretation.

\section{Climate change terms}

Adaptation is an adjustment in natural or human systems in response to actual or expected climate change, which reduces negative impacts or exploits beneficial opportunities (Intergovernmental Panel on Climate Change [IPCC], 2001).

Climate change is any substantial change in climate (e.g. temperature, precipitation, etc.) that occurs over several decades or longer (Environmental Protection Agency [EPA], 2015).

Mitigation is an intervention to reduce the human influences on the climate system, including minimizing greenhouse gas emissions and enhancing greenhouse sinks (EPA, 2015). 


\section{Climate change focus areas}

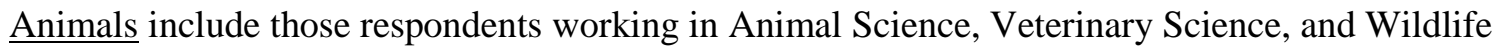
Management.

Cropping Systems refers to those respondents working in Agronomy, Soil Sciences, Horticulture, and Lawn and Garden.

Engineering relates only to the engineering fields of Agricultural Engineering, Biological Engineering, and Structural Engineering.

Environment refers to those respondents working in Ecosystem Science, Ecosystem Management, and Environmental Policy.

Food Science and Nutrition includes those respondents working in the disciplines of Food Science and Nutritional Science.

Forestry includes Agroforestry, Forest Ecology, and Forest Management.

Natural Resources refer to those respondents working in Aquatic Resources, Earth and Atmospheric Sciences, Natural Resource Management, and Water Resources.

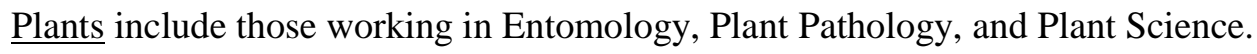

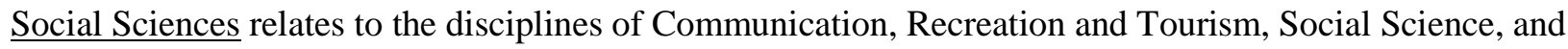
Agricultural Economics.

\section{Climate impact activities}

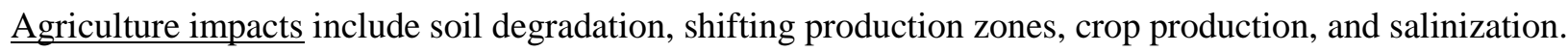

$\underline{\text { Sea and aquatic ecosystems impacts include aquatic ecosystem changes, ocean acidification, sea level }}$ rise, and storm surge. 
Ecosystem impacts include pests, diseases, invasives, biodiversity loss, changes in wildlife, habitat loss, hydrologic changes, biogeochemical changes, and air quality.

Forest impacts include fire risk, wildfires, shifting zones in forestry systems, and forest ecosystem changes.

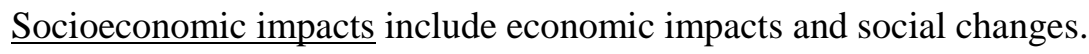

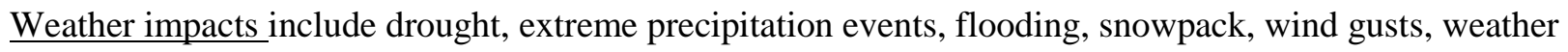
variability, and temperature extremes.

Climate adaptation activities

Animal adaptation includes animal breeding and livestock system management.

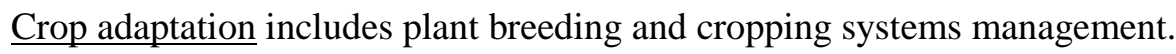

IPM Adaptation refers to Integrated Pest Management (IPM).

Planning adaptation includes land use planning, natural disaster or hazard planning, and the development of decision-support tools.

Policy adaptation includes policies, regulations, insurance programs, and incentive programs.

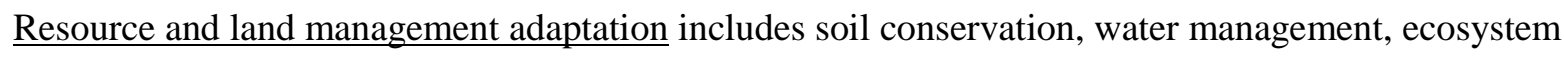
restoration, on-farm diversification, biodiversity conservation, and infrastructure changes, resource monitoring, and landscape connectivity.

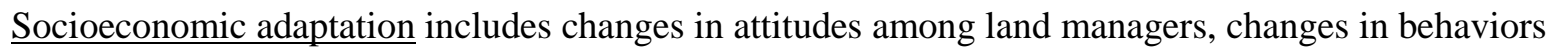
among land managers, social movements, and political movements. 


\section{Climate mitigation}

Energy mitigation includes energy conservation, wind power, hydroelectricity, solar energy, and biomass energy.

Farm management mitigation includes soil conservation, crop management, livestock management, and nutrient management.

Forestry mitigation includes afforestation, avoiding deforestation, and urban forestry.

Greenhouse gas (GHG) mitigation includes carbon sequestration, greenhouse gas assessments or modeling, and forest carbon management.

Policy and planning mitigation includes land use planning, policies, and regulations.

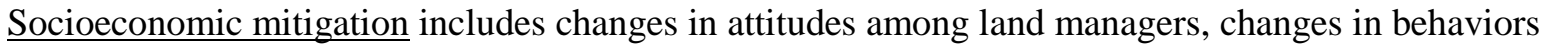
among land managers, social movements, political movements, education, and outreach.

\section{Findings}

\section{Objective 1: Profile of the Respondents}

The following findings relate to respondents' (with at least $1 \%$ of time dedicate to climate change activities) appointments, disciplinary focus areas for climate change activities, universities, gender, and age. Table 3 presents the profile of respondents. A relatively close percentage of respondents were either research faculty (44.2\%) or Extension faculty or educators (49.0\%), and the overwhelming majority (70.9\%) had only $1-20 \%$ of their time dedicate to climate change activities. The top five focus areas in which respondents conducted their climate change work were Natural Resources (38.8\%), Cropping Systems (30.7\%), Social Sciences (22.9\%), Plants (22.0\%), and Environment (20.8\%). Cornell University and Penn State had the most respondents, comprising $26.8 \%$ and $13.0 \%$ of respondents respectively. It should be noted that for the results on disciplinary areas, respondents could indicate that they worked in 
more than one area. Therefore, the percentages indicated in Table 3 for each disciplinary area should be understood as a percentage of the total number of respondents, and each disciplinary area should not be interpreted as mutually exclusive from one another. For all other data presented in Table 3, the percentages will total $100 \%$ because each category is mutually exclusive. 
Table 3. Profile of respondents with at least $1 \%$ of time dedicated to climate change activities.

\begin{tabular}{|c|c|c|}
\hline & $\mathrm{N}$ & $\%$ \\
\hline \multicolumn{3}{|l|}{ University appointment $(\mathrm{N}=550)$} \\
\hline Extension agent/educator & 145 & 26.3 \\
\hline Faculty with extension appointment & 123 & 22.7 \\
\hline Research faculty (no extension appointment) & 243 & 44.2 \\
\hline Administrator/director & 37 & 6.7 \\
\hline \multicolumn{3}{|l|}{$\%$ of time dedicated to climate change $(\mathrm{N}=554)$} \\
\hline $1-20 \%$ & 393 & 70.9 \\
\hline $21-40 \%$ & 84 & 15.2 \\
\hline $41-60 \%$ & 30 & 5.4 \\
\hline $61-80 \%$ & 26 & 4.7 \\
\hline $81-100 \%$ & 21 & 3.8 \\
\hline \multicolumn{3}{|l|}{ Climate change focus areas* $(\mathrm{N}=554)$} \\
\hline Animals & 82 & 14.8 \\
\hline Cropping Systems & 170 & 30.7 \\
\hline Engineering & 38 & 6.9 \\
\hline Environment & 115 & 20.8 \\
\hline Food Science and Nutrition & 25 & 4.5 \\
\hline Forestry & 70 & 12.6 \\
\hline Natural Resources & 215 & 38.8 \\
\hline Plants & 122 & 22.0 \\
\hline Social Sciences & 127 & 22.9 \\
\hline Other & 78 & 14.1 \\
\hline \multicolumn{3}{|l|}{ University $(\mathrm{N}=553)$} \\
\hline UConn & 29 & 5.2 \\
\hline Cornell & 148 & 26.8 \\
\hline UD & 25 & 4.2 \\
\hline DSU & 5 & 0.9 \\
\hline UDC & 2 & 0.4 \\
\hline UM & 38 & 6.9 \\
\hline UMD & 35 & 6.3 \\
\hline UMES & 6 & 1.1 \\
\hline UMass & 27 & 4.9 \\
\hline UNH & 39 & 7.1 \\
\hline PSU & 72 & 13.0 \\
\hline URI & 21 & 3.8 \\
\hline Rutgers & 45 & 8.1 \\
\hline UVM & 38 & 6.9 \\
\hline WVU & 18 & 3.3 \\
\hline WVSU & 5 & 0.9 \\
\hline \multicolumn{3}{|l|}{ Gender $(\mathrm{N}=539)$} \\
\hline Female & 218 & 59.4 \\
\hline Male & 320 & 40.4 \\
\hline Age $(\mathrm{N}=453)$ & $52.4(M)$ & $11.3(S D)$ \\
\hline
\end{tabular}

\footnotetext{
*Respondents could check up to three focus areas.
} 
Geographical focus of climate change activities

Respondents were asked to identify where they conduct their climate change activities. Regional categorizations for the United States corresponded to the geographic coverage of the various USDA Climate Hubs. According to the findings, the respondents overwhelmingly dedicated their efforts to the Northeastern U.S. (Table 4). Among the 554 respondents, 500 (90.3\%) worked on climate change activities in the Northeast. Respondents were able to indicate if they worked in more than one geographical region and therefore the percentages in Table 4 do not cumulatively add up to $100 \%$.

Table 4. Geographical focus of climate change activities* $(\mathrm{N}=554)$

\begin{tabular}{lcc}
\hline \multicolumn{1}{c}{ Region } & $\mathrm{N}$ & $\%$ \\
\hline Northeast & 500 & 90.3 \\
Southeast & 44 & 7.9 \\
Midwest & 44 & 7.9 \\
Southern Plains & 16 & 2.9 \\
Northern Plains & 16 & 2.9 \\
Southwest & 32 & 5.7 \\
Northwest & 37 & 6.6 \\
International & 97 & 17.5 \\
\hline Respondents could indicate that they worked in more than one region.
\end{tabular}

\section{Objective 2: Content of Current Climate Change Activities}

To better understand the current climate change activities on which land-grant universities are working, research and Extension activities were considered independently. According to the findings, similar impacts are being considered through both research and Extension activities based on the frequency of respondents who indicated that their work relates to specific climate change impacts. The top three impacts receiving attention are the same for both research and Extension activities: ecosystem impacts, weather impacts, and agriculture impacts (Table 5). Because respondents could indicate that they worked in more than one area, percentages in Table 5 do not total 100\%. For more specific insight into the climate activities that the various disciplinary focus areas are concentrating, Appendix A contains tables that disaggregate climate activities related to impacts, adaptation, and mitigation according to disciplinary focus areas. 
Table 5. Percentage of respondents conducting research and Extension activities on specific climate impact content areas

\begin{tabular}{lcc} 
& \multicolumn{2}{c}{ Climate Change Impacts* (N=554) } \\
\hline Rank & Research Activities & Extension Activities \\
\hline 1$)$ & Ecosystem $(48.2 \%)$ & Ecosystem (42.8\%) \\
2) & Weather (37.4\%) & Weather (35.2\%) \\
3) & Agriculture (30.9\%) & Agriculture (30.3\%) \\
4) & Aquatic and Sea (17.7\%) & Socioeconomic (19.5\%) \\
5) & Socioeconomic (17.3\%) & Aquatic and Sea (13.5\%) \\
6) & Forest (13.2\%) & Forests (13.4\%)
\end{tabular}

*Respondents could indicate that they worked on more than one activity

Similarities between research and Extension activities also existed for the activities conducted on climate change adaptation. Both research and Extension are dedicating the most effort to resource and land management adaptation (Table 6). Planning and IPM adaptation also shared top three status for both research and Extension activities. The only difference that existed between research and Extension was that researchers are highly prioritizing crop adaptation. As with climate change impact areas, respondents could indicate that they worked in more than one area, meaning that each adaptation activity should not be interpreted as mutually exclusive. 
Table 6. Percentage of respondents conducting research and Extension activities on specific climate adaptation content areas

\begin{tabular}{lcc}
\hline & \multicolumn{2}{c}{ Climate Change Adaptation* $(\mathbf{N = 5 5 4 )}$} \\
\hline Rank & Research Activities & Extension Activities \\
\hline 1$)$ & Resource and Land Management (41.3\%) & Resource and Land Management (42.8\%) \\
$2)$ & Crops (18.6\%) & Planning (22.4\%) \\
$3)$ & Planning (18.6\%) & IPM (20.4\%) \\
$4)$ & IPM (13.0\%) & Crops (20.0\%) \\
$5)$ & Socioeconomic (12.5\%) & Socioeconomic (15.9\%) \\
$6)$ & Policy (9.0\%) & Policy (12.5\%) \\
$7)$ & Animals (7.2\%) & Animals (9.4\%) \\
\hline
\end{tabular}

* Respondents could indicate that they worked on more than one activity.

While there were similar findings between research and Extension activities for climate change impacts and adaptation, some variation existed regarding climate change mitigation (Table 7). Research mitigation activities are primarily dedicated to 1) farm management, 2) socioeconomic, and 3) energy, while Extension mitigation activities are focusing on 1) socioeconomic, 2) farm management, and 3) policy and planning. Because respondents could indicate that they worked in more than one area, percentages in Table 7 do not total $100 \%$.

Table 7. Percentage of respondents conducting research and Extension activities on specific climate mitigation content areas

\begin{tabular}{lcc}
\hline & \multicolumn{2}{c}{ Climate Change Mitigation*(N=554) } \\
\hline Rank & Research Activities & Extension Activities \\
\hline 1$)$ & Farm Management $(29.2 \%)$ & Socioeconomic $(37.5 \%)$ \\
$2)$ & Socioeconomic $(20.4 \%)$ & Farm Management $(29.8 \%)$ \\
$3)$ & Energy (17.3\%) & Policy and Planning (17.5\%) \\
$4)$ & Greenhouse Gas (17.0\%) & Energy $(16.2 \%)$ \\
$5)$ & Policy and Planning (15.9\%) & Forestry (11.7\%) \\
$6)$ & Forestry (9.9\%) & Greenhouse Gas (11.4\%)
\end{tabular}

* Respondents could indicate that they worked on more than one activity. 


\section{Professional activities on climate change}

In addition to exploring the specific content areas of climate change activities, respondents were also asked to identify the kinds of professional activities related to climate change in which they engaged in the past year (Figure 1). The findings indicate that while a majority $(67 \%)$ of respondents participates in trainings and workshops on climate change, a minority is filling leadership roles (31\%). Although most of respondents indicated that they included climate change concepts in Extension programs (60\%) and undergraduate courses (59\%), only $43 \%$ included climate change concepts in graduate level courses. In the past year, $44 \%$ of respondents shared their climate change work with colleagues at conferences, $33 \%$ published peer-reviewed articles and 25\% published factsheets, bulletins, or newsletters.

Figure 1. Professional activities on climate change in the past year.

Participated in a training or workshop $(\mathrm{N}=518)$

Included concepts in Extension programs $(\mathrm{N}=511)$

Included concepts in undergrad courses $(\mathrm{N}=516)$

Presented at conferences $(\mathrm{N}=501)$

Included concepts in grad courses $(\mathrm{N}=494)$

Published peer-reviewed articles $(\mathrm{N}=502)$

Led a training or workshop $(\mathrm{N}=500)$

Published factsheets, bulletins, etc. $(\mathrm{N}=492)$

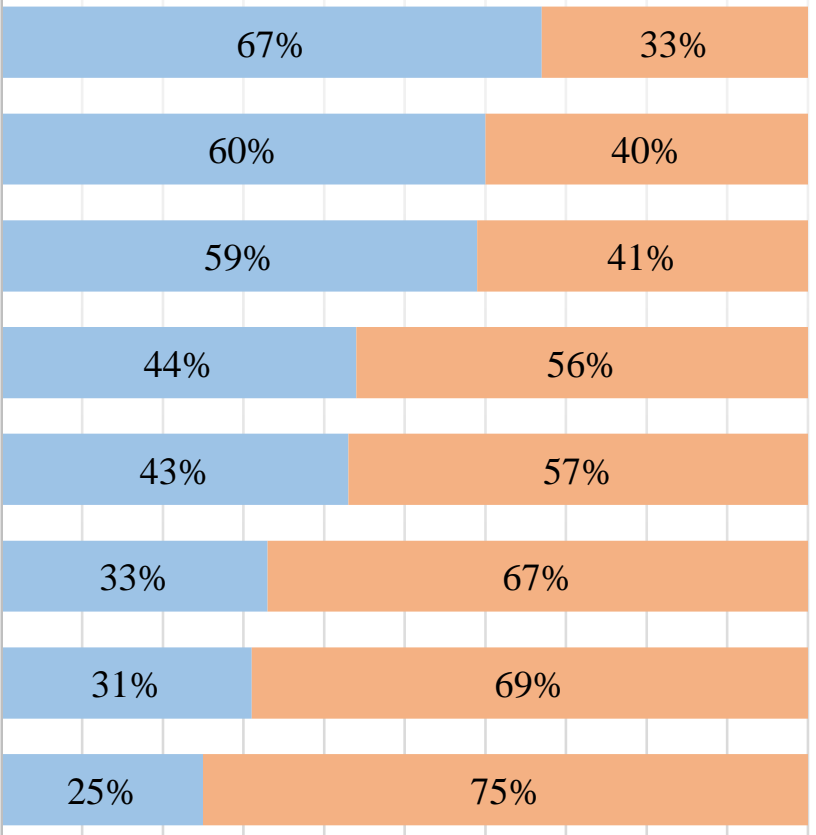

$0 \% \quad 10 \% \quad 20 \% 30 \% \quad 40 \% 50 \% \quad 60 \% 70 \% 80 \% 90 \% 100 \%$

At least once $\quad$ Never

To further explore the kinds of professional activities to which respondents dedicate their climate change activities, data collection also included questions about the resources that have been developed. Of the respondents who developed climate change resources, 29\% ( $\mathrm{N}=147$ of 507) have created tools, 25\% 
( $N=126$ of 504) have developed programs, and 19\% ( $N=95$ of 502) have developed guidelines. Through open-ended responses, respondents also had the opportunity to describe the nature of the resources they have developed. Of the 554 respondents, 275 provided written responses, which were coded and categorized according to the climate change topic and the type of resource developed. Responses relevant to more than one category were included in multiple. Table 8 characterizes the data based on preliminary qualitative analysis. Based on the findings, the greatest number of resources that had been developed is on agricultural issue followed by water issues, datasets/guidelines, and decision tools.

Given the increasing emphasis on evaluating program impacts, data were also collected regarding the climate change program evaluation activities among respondents. Among those who indicated that evaluation was relevant to their position $(\mathrm{N}=445), 32 \%(\mathrm{~N}=143)$ had not conducted any form of evaluation, while $51 \%(\mathrm{~N}=225)$ had only done so informally. Only $17 \%$ of respondents $(\mathrm{N}=77)$ had conducted more intensive evaluations through formative and/or summative evaluations. 
Table 8. Number of types of resources on different climate topics.

\section{Types of Resources}

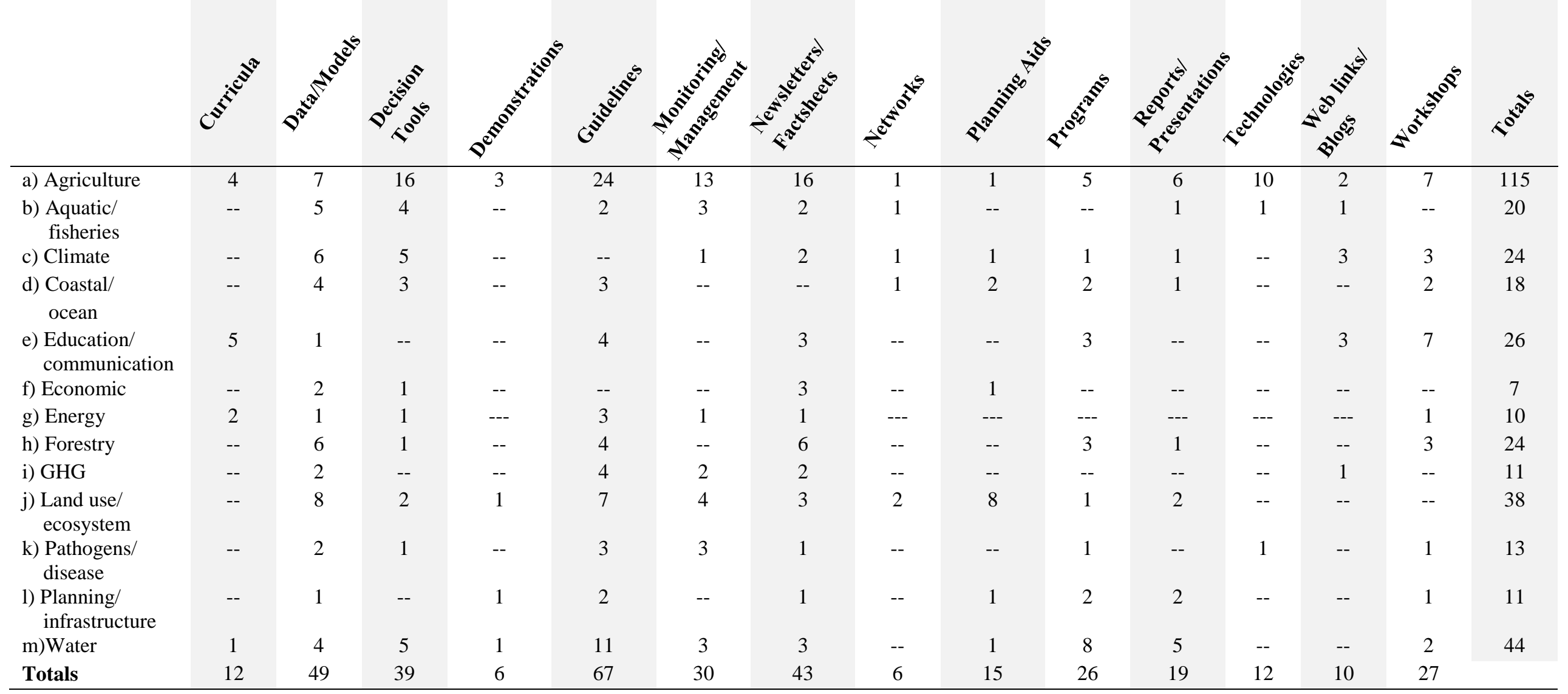




\section{Objective 3: Preferred Delivery Methods}

Respondents were asked to assess how effectively they perceive various delivery methods to disseminate information and change practices or behaviors related to climate change. The number of respondents who answered this series of items ranged from 494 to 527 (of 554). The usefulness of each item was measured on a scale of 1=Not at all useful to 4=Very useful. The results (Figure 2) indicate that across all items, respondents perceived that each method is more useful to disseminate information than to change practices or behaviors. In terms of disseminating information, respondents indicated that they perceived field tours $(M=3.18)$, videos $(M=3.16)$, websites $(M=3.12)$, and workshops $(M=3.08)$ as useful delivery methods. Field tours $(M=3.13)$ and workshops $(M=3.03)$ were also identified as useful mechanisms to change practices or behaviors.

Figure 2. Usefulness of delivery methods to disseminate climate change information and change climate change practices or behaviors.*

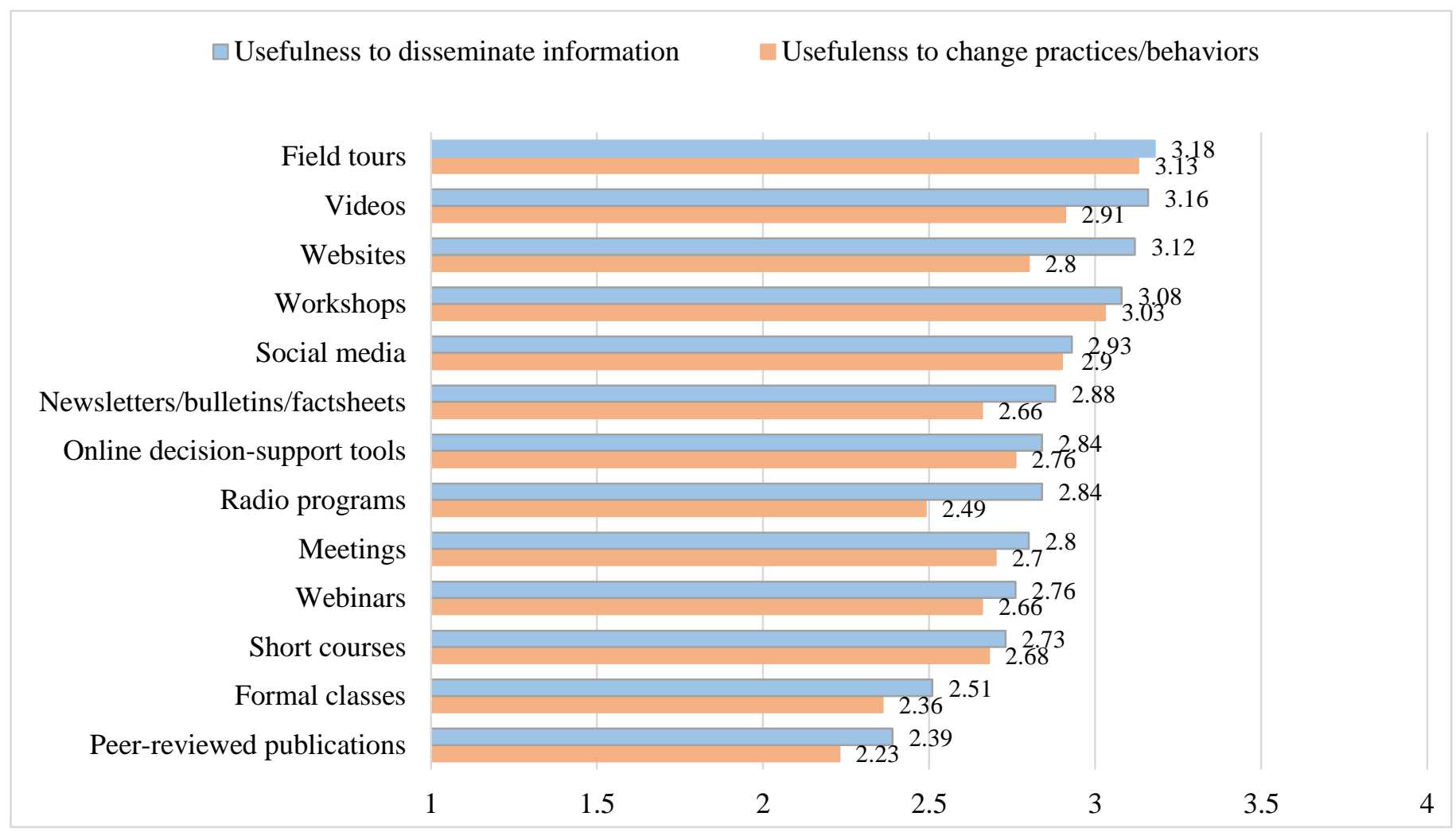

*Means calculated based on measurements of $1=$ Not at all useful to $4=$ Very useful. 


\section{Objective 4: Future Priorities and Willingness to Participate in Climate Change Activities}

To assess the future priorities of land-grant universities regarding their work on climate change, respondents were asked to rank the top five most important activities to address in the future among a series of 17 activities. Respondents ranked individual items from $1=1^{\text {st }}$ most important to $5=5^{\text {th }}$ most important. To analyze the data, respondents were disaggregated into three groups: research faculty, Extension faculty, and Extension educators. The findings indicate commonalities among the three groups in terms of the most important activities that land-grant universities need to pursue (Table 9). Making the top five for all three groups were training Extension educators and providing them support on climate change, developing decision-support tools and websites, and conducting cost-benefit analyses on implementing adaptation/mitigation strategies. Securing funding for applied research was a top five priority for research faculty and Extension faculty and was the seventh priority for Extension educators. In addition, better understanding land managers' attitudes and needs for research and Extension made the top five for research faculty and Extension educators and was sixth for Extension faculty. For ease of reading and interpretation, Table 9 groups the rankings of the 17 activities into the top 5 (1-5), middle 5 (610), and bottom 7 (11-17). 
Table 9. Rankings of future priorities of research faculty, Extension faculty, and Extension educators for climate change activities at land-grant universities.

\begin{tabular}{|c|c|c|c|}
\hline Rank & Research Faculty & Extension Faculty & Extension Educators \\
\hline 1) & $\begin{array}{l}\text { Securing funding for applied } \\
\text { research }\end{array}$ & $\begin{array}{c}\text { Training Extension educators and } \\
\text { providing them support on climate } \\
\text { change }\end{array}$ & $\begin{array}{c}\text { Training Extension educators and } \\
\text { providing them support on climate } \\
\text { change }\end{array}$ \\
\hline 2) & Securing funding for basic research & $\begin{array}{l}\text { Securing funding for applied } \\
\text { research }\end{array}$ & $\begin{array}{c}\text { Developing decision-support tools and } \\
\text { websites for extension, consultants, and } \\
\text { farmers }\end{array}$ \\
\hline 3) & $\begin{array}{l}\text { Developing decision-support tools } \\
\text { and websites for extension, } \\
\text { consultants, and farmers }\end{array}$ & $\begin{array}{l}\text { Developing decision-support tools } \\
\text { and websites for extension, } \\
\text { consultants, and farmers }\end{array}$ & $\begin{array}{c}\text { Better understanding land managers' } \\
\text { attitudes and needs for research and } \\
\text { Extension }\end{array}$ \\
\hline 4) & $\begin{array}{c}\text { Better understanding land managers' } \\
\text { attitudes and needs for research and } \\
\text { Extension }\end{array}$ & $\begin{array}{c}\text { Conducting cost-benefit analyses on } \\
\text { implementing adaptation/mitigation } \\
\text { strategies }\end{array}$ & $\begin{array}{c}\text { Conducting cost-benefit analyses on } \\
\text { implementing adaptation/mitigation } \\
\text { strategies }\end{array}$ \\
\hline 5) & $\begin{array}{c}\text { Tie: Conducting cost-benefit } \\
\text { analyses on implementing } \\
\text { adaptation/mitigation strategies } \\
\text { and } \\
\text { Training Extension educators and } \\
\text { providing them support on climate } \\
\text { change }\end{array}$ & $\begin{array}{l}\text { Developing new toolkits of } \\
\text { adaptation and mitigation resources } \\
\text { and materials }\end{array}$ & $\begin{array}{l}\text { Developing new toolkits of adaptation } \\
\text { and mitigation resources and materials }\end{array}$ \\
\hline 6) & $\begin{array}{c}\text { Developing new models and seasonal } \\
\text { forecasts }\end{array}$ & $\begin{array}{l}\text { Better understanding land } \\
\text { managers' attitudes and needs for } \\
\text { research and Extension }\end{array}$ & $\begin{array}{c}\text { Providing training to land managers on } \\
\text { climate change }\end{array}$ \\
\hline 7) & $\begin{array}{c}\text { Developing new toolkits of } \\
\text { adaptation and mitigation resources } \\
\text { and materials }\end{array}$ & $\begin{array}{l}\text { Developing new course curriculum } \\
\text { for university students }\end{array}$ & Securing funding for applied research \\
\hline 8) & Making policy recommendations & $\begin{array}{l}\text { Developing new models and } \\
\text { seasonal forecasts }\end{array}$ & $\begin{array}{c}\text { Developing new models and seasonal } \\
\text { forecasts }\end{array}$ \\
\hline 9) & $\begin{array}{l}\text { Developing new course curriculum } \\
\text { for university students }\end{array}$ & $\begin{array}{l}\text { Tie: Providing training to land } \\
\text { managers on climate change } \\
\text { and } \\
\text { Making policy recommendations }\end{array}$ & Creating networks among professionals \\
\hline 10) & $\begin{array}{l}\text { Providing training to land managers } \\
\text { on climate change }\end{array}$ & Securing funding for basic research & $\begin{array}{l}\text { Supporting networks of land managers } \\
\text { to share information }\end{array}$ \\
\hline 11) & Conducting risk assessments & $\begin{array}{c}\text { Tie: Supporting networks of land } \\
\text { managers to share information } \\
\text { and } \\
\text { Creating networks among } \\
\text { professionals }\end{array}$ & Securing funding for basic research \\
\hline 12) & $\begin{array}{l}\text { Supporting networks of land } \\
\text { managers to share information }\end{array}$ & Conducting risk assessments & Conducting risk assessments \\
\hline 13) & $\begin{array}{c}\text { Developing planning and geospatial } \\
\text { tools }\end{array}$ & $\begin{array}{c}\text { Developing planning and geospatial } \\
\text { tools }\end{array}$ & $\begin{array}{c}\text { Developing new course curriculum for } \\
\text { university students }\end{array}$ \\
\hline 14) & $\begin{array}{l}\text { Creating networks among } \\
\text { professionals }\end{array}$ & Creating early warning systems & Creating early warning systems \\
\hline 15) & Creating early warning systems & Monitoring resource consumption & Making policy recommendations \\
\hline 16) & Monitoring resource consumption & --- & $\begin{array}{c}\text { Developing planning and geospatial } \\
\text { tools }\end{array}$ \\
\hline 17) & --- & --- & Monitoring resource consumption \\
\hline
\end{tabular}


Respondents also indicated their willingness to participate (on a scale of $1=$ Not at all willing to $5=$ Very willing) in various climate change activities in the future. In general, the findings indicate that while respondents are willing to collaborate on and participate in activities, they are less willing to lead activities (Figure 3). Research faculty were most willing to collaborate on regional research initiatives with other institutions $(M=4.22)$, although they indicated some degree of willingness to participate in all activities (mean above 3 ) except for organizing regional conferences. Respondents affiliated with Extension were also willing to participate in most activities, although the means on developing graduate course, developing undergraduate course, leading regional research initiatives with other institutions, and organizing regional conferences indicated that they were less willing to engage in those activities.

Figure 3. Willingness to participate in future climate change activities among research and Extension respondents.*

Collaborate on inter-institutional research initatives $(\mathrm{N}=500)$

Collaborate on inter-institutional programming initatives $(\mathrm{N}=498)$

Attend regional conferences $(\mathrm{N}=498)$

Develop educational materials $(\mathrm{N}=504)$

Develop graduate courses $(\mathrm{N}=498)$

Develop undergraduate courses $(\mathrm{N}=499)$

Deliver programs on climate issues $(\mathrm{N}=503)$

Attend workshops on communication strategies $(\mathrm{N}=500)$

Lead inter-institutional regional research initiatives $(\mathrm{N}=496)$

Lead inter-institutional regional programming initiatives $(\mathrm{N}=497)$

Attend workshops on decision-support tools $(\mathrm{N}=500)$

Organize regional conferences $(\mathrm{N}=499)$

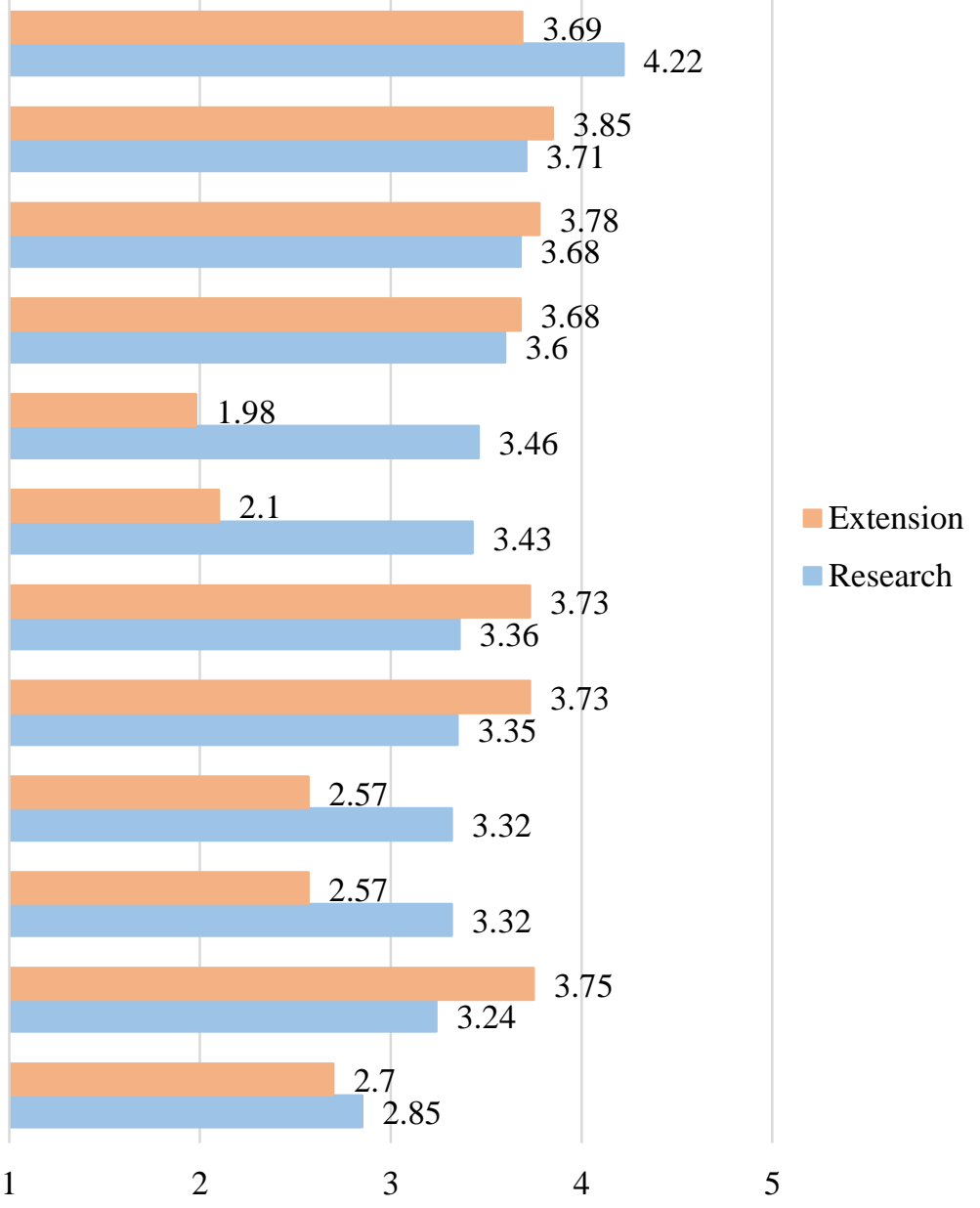

2
3

*Means calculated based on scale of $1=$ Not at all willing to 5=Very willing. 


\section{Objective 5: Barriers to Addressing Climate Change}

To add nuance to the findings related to future priorities and willingness to participate in future activities, respondents were also asked to indicate various barriers in addressing climate change issues. Barriers were grouped in three categories: informational availability, workplace, and target audience and measured on a scale from 1=Not at all a barrier to 5=A major barrier. According to the findings, respondents affiliated with Extension consistently perceived that the barriers they confronted were more challenging than the research respondents (Figures 4, 5, 6).

When considering information availability barriers in particular, both research and Extension respondents indicated that the lack of information and options available to them that were specific to local needs were among the most difficult barriers (Figure 4). For both groups, the means for lack of information to specific needs, lack of mitigation options specific to local needs, and lack of adaptation options specific to local needs were all above the scale midpoint (3). Some divergences in barrier perceptions existed for information availability between research and Extension respondents. For example, while research faculty perceived that lack of training was not a barrier, Extension respondents indicated that lack of training posed a slight barrier. While both groups did not perceive that the lack of clarity about the causes of climate change was a barrier, the Extension respondents approached the midpoint much more closely than research faculty. 
Figure 4. Mean scores of information availability barriers to addressing climate change among research and Extension respondents.*

Information not specific to local needs $(\mathrm{N}=493)$

Lack of adaptation options specific to local needs $(\mathrm{N}=490)$

Lack of mitigation options specific to local needs $(\mathrm{N}=495)$

Lack of decision-making tools $(\mathrm{N}=486)$

Lack of training $(\mathrm{N}=494)$

Too much information $(\mathrm{N}=491)$

Lack of clarity about causes $(\mathrm{N}=491)$

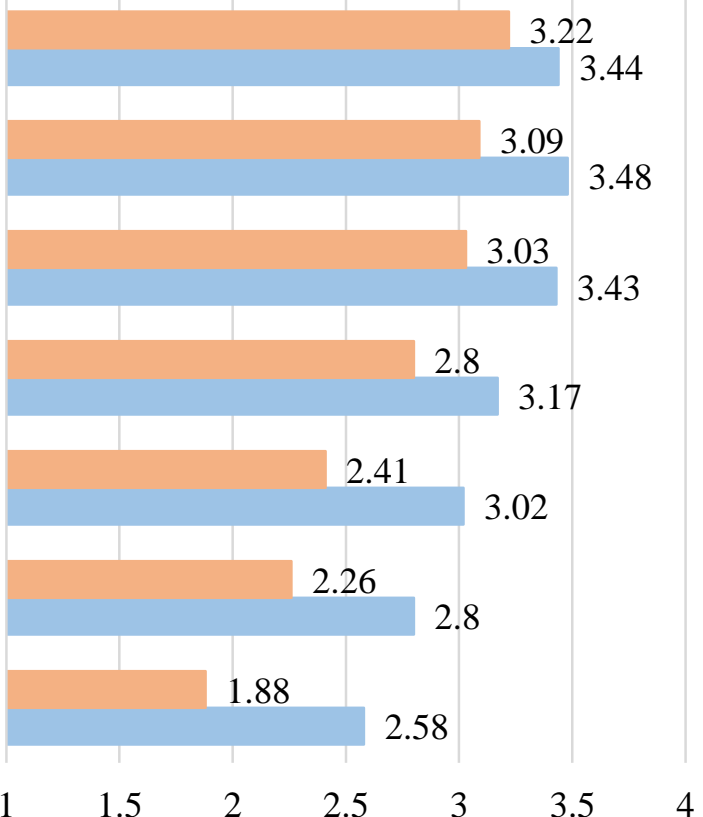

Researchers Extension faculty and educators

*Means calculated based on scale of $1=$ Not at all a barrier to $5=\mathrm{A}$ major barrier

In terms of workplace barriers, the only barriers to both research and Extension respondents were lack of time and lack of funding (Figure 5). For both groups, the mean scores for these two items were well above the scale's midpoint (3).

Figure 5. Mean scores of workplace barriers to addressing climate change among research and Extension respondents.*

Lack of funding $(\mathrm{N}=503)$

Not enough time $(\mathrm{N}=502)$

Topic is politically contentious $(\mathrm{N}=499)$

Not part of job responsibility $(\mathrm{N}=500)$

Not viewed as priority by supervisor $(\mathrm{N}=498)$

Not priority for promotion/tenure $(\mathrm{N}=494)$

Not interested $(\mathrm{N}=495)$

$1-15=-2$

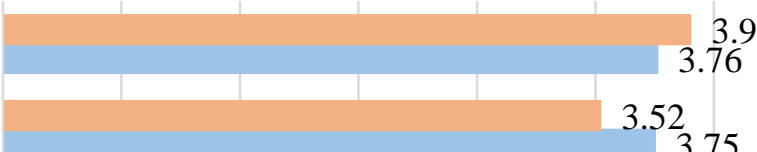

3.75
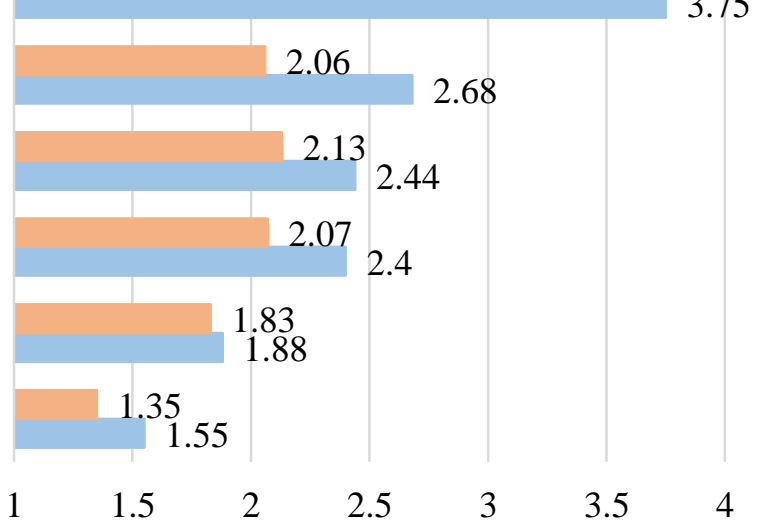

$4.5 \quad 5$

$\square$ Researchers Extension faculty and educators 
Respondents were also asked to identify the barriers they confronted with their target audiences. For these barriers, both research and Extension perceived that the most difficult barrier was the perception of their target audiences that changing their practices was too costly (Figure 6). Both research and Extension respondents also indicated that the real costs of changing practices is too much. Other items also identified as barriers by the respondents include the perception among target audiences that it is too risky to adopt new technologies and that their target audiences lack awareness regarding the impacts of climate change. For Extension respondents, the lack of priority placed on climate change by their target audiences posed a barrier, contrasting the research respondents. Similarly, Extension respondents struggle with the political sensitivity of climate change with their target audiences, an issue felt less acutely by the research respondents who typically have less direct contact with land managers.

Figure 7. Mean scores of target audience barriers to addressing climate change among research and Extension respondents.*

Perception that changing practices is too costly $(\mathrm{N}=499)$

Real costs are too high to change practices $(\mathrm{N}=493)$

Perception that risk is to high to adopt new technologies $(\mathrm{N}=490)$

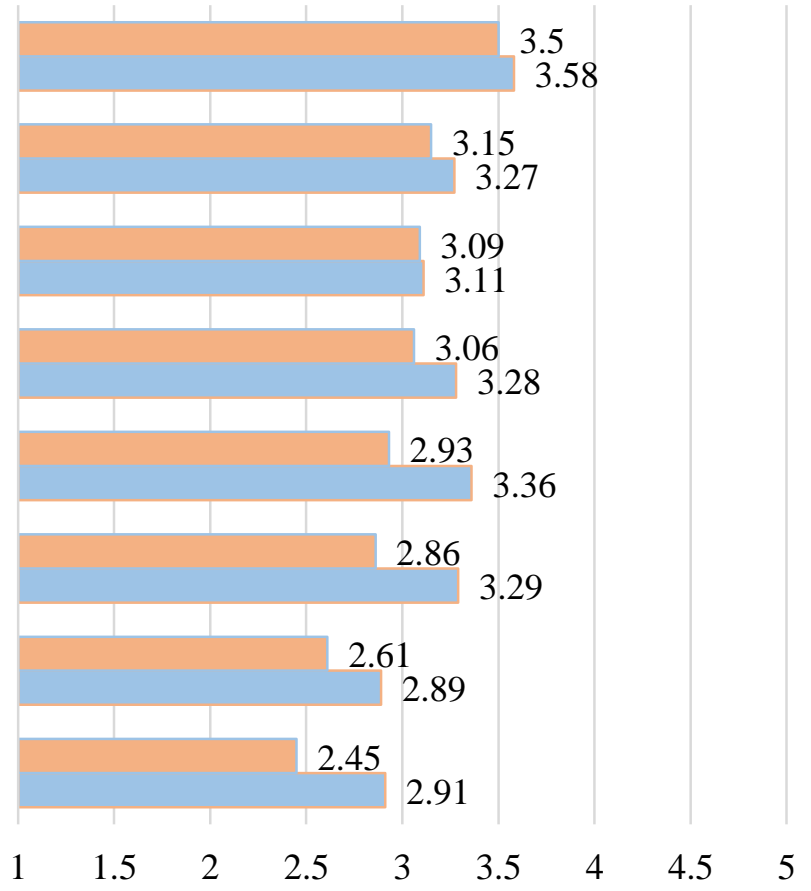

Actual risk is too high to adopt new technologies $(\mathrm{N}=493)$

Too difficult an issue to communicate $(\mathrm{N}=495)$

$$
(\mathrm{N}=499)
$$

Not a priority issue $(\mathrm{N}=497)$

Topic is contentious $(\mathrm{N}=497)$

$\square$ Researchers $\quad$ Extension faculty and educators

*Means calculated based on scale of $1=$ Not at all a barrier to 5=A major barrier 


\section{Conclusions}

This report provides a regional overview of the current climate change activities related to agricultural, forestry, and natural resource research and Extension work being conducted across the 16 land-grant universities in the Northeast, as well the perspectives and future priorities among research faculty and Extension professionals at those universities. The findings detail climate focus areas, professional activities, future needs, and potential barriers. These findings should be utilized in ways that leverage existing strengths and mitigate weaknesses. For example, climate change work around resource and land management, agriculture, energy, IPM, and policy issues among both research faculty and Extension provides potential to build strong, collaborative networks within and across universities. Furthermore, there is general agreement among research faculty, Extension faculty, and Extension educators that future priorities for climate change must be leveraged in ways that ensure that the research that is being conducted is translated in useful and relevant ways for stakeholders. These future goals seem reasonable, given that researchers and Extension professionals are willing to engage in a variety of professional activities that can support collaborative efforts such as participating in regional research and programming initiatives.

As these activities are pursued, the barriers identified by respondents are useful to consider. From the perspectives of the respondents, a major challenge is that climate change information and recommendations are not currently detailed enough or adapted to local conditions, making adaptation and mitigation decisions among farmers, foresters, and natural resource managers more difficult. Stakeholders often want to know specifically what to implement and how to do so, and the findings indicate that universities have not yet developed the materials or tools to give them that detailed information. Furthermore, because climate change is not typically a priority issue for target audiences and is one that is politically charged, the communication difficulties with stakeholders present another important barrier that needs to be addressed if land-grant universities are to maximize their impact. The lack of time and funding available to research faculty and Extension professionals to work on climate change issues - common limitations regardless of research and Extension initiative - cannot be overlooked, particularly given the finding that the majority of respondents only have $1-20 \%$ of their time dedicated to climate change activities. Careful attention must also be given to delivery methods. Respondents considered field tours, workshops, videos, 
and websites were effective delivery mechanisms but the findings indicated that neither videos nor field tours have been commonly developed, suggesting a need for establishing a comprehensive strategy for delivery.

The findings from this Capacity Discovery also lay the groundwork for future research examining the perceptions, practices, and needs of agricultural and natural resource stakeholders as related to climate change adaption and mitigation. As this future work is conducted, they should be combined with the findings documented in this report to help identify how to best leverage the strengths of Northeast land-grant universities to meet the needs of the stakeholders they service.

Collectively, the findings presented in this report point to next steps for the Northeast Climate Hub. Building networks and collaborations, adapting climate information to local conditions, and focusing on the communication of climate science constitute important issues that must be addressed. Doing so will contribute to the impacts of the already impressive array of work occurring across land-grant universities in the Northeast.

\section{References}

Dillman, D.A., Smyth, J.D., \& Christian, L.M. (2009). Internet, mail, and mixed-mode surveys: The Tailored Design Method ( $3^{\text {rd }}$ e.). Hoboken: John Wiley \& Sons.

Environmental Protection Agency [EPA]. (2015). Glossary of climate change terms. Climate change. Retrieved from http://www3.epa.gov/climatechange/glossary.html.

Intergovernmental Panel on Climate Change [IPCC]. (2001). Annex B: Glossary of terms. Climate Change 2001: Synthesis report. Retrieved from http://www.ipcc.ch/ipccreports/tar/vol4/ index.php?idp=204. 
Appendix A. Climate change activities according to disciplinary focus areas.

Table 1. Frequency and percentage of respondents working on climate change impact activities according to focus areas.

\begin{tabular}{|c|c|c|c|c|c|c|c|c|c|}
\hline & & & & & $\begin{array}{c}\text { Focus areas* } \\
\text { N }(\%)\end{array}$ & & & & \\
\hline $\begin{array}{l}\text { Climate Change } \\
\text { Impacts }\end{array}$ & Animals & $\begin{array}{l}\text { Cropping } \\
\text { Systems }\end{array}$ & Engineering & Environment & $\begin{array}{l}\text { Food Science } \\
\text { and Nutrition }\end{array}$ & Forestry & $\begin{array}{c}\text { Natural } \\
\text { Resources }\end{array}$ & Plants & $\begin{array}{c}\text { Social } \\
\text { Sciences }\end{array}$ \\
\hline \multicolumn{10}{|l|}{ Agriculture } \\
\hline Research & $23(31)$ & $127(40)$ & $22(55)$ & $48(69)$ & $10(50)$ & $21(45)$ & $62(51)$ & $96(52)$ & $43(42)$ \\
\hline Extension & $51(69)$ & $187(60)$ & $18(45)$ & $30(31)$ & $10(50)$ & $26(55)$ & $59(49)$ & $89(48)$ & $59(58)$ \\
\hline Total & $74(100)$ & $314(100)$ & $40(100)$ & $78(100)$ & $20(100)$ & $47(100)$ & $121(100)$ & $185(100)$ & $102(100)$ \\
\hline \multicolumn{10}{|l|}{ Aquatic and sea } \\
\hline Research & $19(61)$ & $6(27)$ & $7(70)$ & $60(64)$ & $6(67)$ & $6(35)$ & $101(58)$ & $3(33)$ & $31(52)$ \\
\hline Extension & $12(39)$ & $16(73)$ & $3(30)$ & $34(36)$ & $3(33)$ & $11(65)$ & $74(42)$ & $6(67)$ & $29(48)$ \\
\hline Total & $31(100)$ & $22(100)$ & $10(100)$ & $94(100)$ & $9(100)$ & $17(100)$ & $175(100)$ & $9(100)$ & $60(100)$ \\
\hline \multicolumn{10}{|l|}{ Ecosystem } \\
\hline Research & $60(46)$ & $84(31)$ & $25(56)$ & $94(62)$ & $13(50)$ & $53(51)$ & $146(54)$ & $119(53)$ & $42(38)$ \\
\hline Extension & $70(54)$ & $183(69)$ & $20(44)$ & $58(38)$ & $13(50)$ & $50(49)$ & $123(46)$ & $105(47)$ & $68(62)$ \\
\hline Total & $130(100)$ & $267(100)$ & $45(100)$ & $152(100)$ & $26(100)$ & $103(100)$ & $269(100)$ & $224(100)$ & $110(100)$ \\
\hline \multicolumn{10}{|l|}{ Forests } \\
\hline Research & 18 (49) & $14(27)$ & $4(36)$ & $36(65)$ & $2(25)$ & $45(53)$ & $40(43)$ & $14(52)$ & $10(27)$ \\
\hline Extension & $19(51)$ & $38(73)$ & $7(64)$ & $19(35)$ & $6(75)$ & $40(47)$ & $51(57)$ & $13(48)$ & $27(73)$ \\
\hline Total & 37 (100) & $52(100)$ & $11(100)$ & $55(100)$ & $8(100)$ & $85(100)$ & $91(100)$ & 27 (100) & 37 (100) \\
\hline \multicolumn{10}{|l|}{ Socioeconomic } \\
\hline Research & $8(24)$ & $15(18)$ & $7(39)$ & $46(62)$ & $6(43)$ & $15(42)$ & $56(48)$ & $12(29)$ & $81(52)$ \\
\hline Extension & $26(76)$ & $70(82)$ & $11(61)$ & $28(38)$ & $8(57)$ & $21(58)$ & $61(52)$ & $29(71)$ & $76(48)$ \\
\hline Total & $34(100)$ & $85(100)$ & $18(100)$ & $74(100)$ & $14(100)$ & $36(100)$ & $117(100)$ & $41(100)$ & 157 (100) \\
\hline \multicolumn{10}{|l|}{ Weather } \\
\hline Research & $31(38)$ & $72(33)$ & $24(53)$ & $66(61)$ & $12(50)$ & $37(57)$ & $113(53)$ & $75(52)$ & $48(39)$ \\
\hline Extension & $51(68)$ & $146(67)$ & $21(47)$ & 43 (39) & $12(50)$ & $28(43)$ & $99(47)$ & $70(48)$ & $75(61)$ \\
\hline Total & $82(100)$ & $218(100)$ & $45(100)$ & $109(100)$ & $24(100)$ & $65(100)$ & $212(100)$ & $145(100)$ & $123(100)$ \\
\hline
\end{tabular}

* Numbers in parentheses represent percentages. 
Table 2. Frequency and percentage of respondents working climate change adaptation activities according to focus areas.

\begin{tabular}{|c|c|c|c|c|c|c|c|c|c|}
\hline \multirow[b]{2}{*}{$\begin{array}{l}\text { Climate Change } \\
\text { Adaptation }\end{array}$} & \multicolumn{9}{|c|}{$\begin{array}{c}\text { Focus areas* } \\
\mathrm{N}(\%)\end{array}$} \\
\hline & Animals & $\begin{array}{l}\text { Cropping } \\
\text { Systems }\end{array}$ & Engineering & Environment & $\begin{array}{l}\text { Food Science } \\
\text { and Nutrition }\end{array}$ & Forestry & $\begin{array}{c}\text { Natural } \\
\text { Resources }\end{array}$ & Plants & $\begin{array}{c}\text { Social } \\
\text { Sciences }\end{array}$ \\
\hline \multicolumn{10}{|l|}{ Animal } \\
\hline Research & $168(74)$ & $8(16)$ & $6(35)$ & $11(50)$ & $7(54)$ & $6(60)$ & $13(43)$ & $2(25)$ & $11(29)$ \\
\hline Extension & $58(26)$ & $42(84)$ & $11(65)$ & $11(50)$ & $6(46)$ & $4(40)$ & $17(57)$ & $6(75)$ & $27(71)$ \\
\hline Total & $226(100)$ & $50(100)$ & 17 (100) & $22(100)$ & 13 (100) & $10(100)$ & 30 (100) & $8(100)$ & $38(100)$ \\
\hline \multicolumn{10}{|l|}{ Crop } \\
\hline Research & 7 (18) & $76(38)$ & $8(48)$ & $23(55)$ & 9 (64) & $8(67)$ & $27(52)$ & $72(56)$ & $21(38)$ \\
\hline Extension & $31(82)$ & $123(62)$ & $9(52)$ & $19(45)$ & $5(36)$ & $4(33)$ & $25(48)$ & $57(44)$ & $34(62)$ \\
\hline Total & 38 (100) & 199 (100) & 17 (100) & $42(100)$ & 14 (100) & $12(100)$ & $52(100)$ & $129(100)$ & 55 (100) \\
\hline \multicolumn{10}{|l|}{ IPM } \\
\hline Research & $13(36)$ & $39(25)$ & $3(33)$ & $11(42)$ & $5(38)$ & $7(32)$ & $13(28)$ & $55(43)$ & $7(20)$ \\
\hline Extension & $23(64)$ & 117 (75) & $6(67)$ & $15(58)$ & $8(62)$ & $15(68)$ & $34(72)$ & $73(57)$ & $28(80)$ \\
\hline Total & 36 (100) & $156(100)$ & $9(100)$ & $26(100)$ & 13 (100) & $22(100)$ & 47 (100) & $128(100)$ & 35 (100) \\
\hline \multicolumn{10}{|l|}{ Planning } \\
\hline Research & $14(30)$ & $17(22)$ & $3(21)$ & $50(58)$ & $2(18)$ & $9(33)$ & $73(48)$ & $9(28)$ & $44(41)$ \\
\hline Extension & $32(70)$ & $61(78)$ & $11(79)$ & $36(42)$ & $9(82)$ & $18(67)$ & $78(52)$ & $23(72)$ & $63(59)$ \\
\hline Total & $46(100)$ & 78 (100) & 14 (100) & 86 (100) & $11(100)$ & 27 (100) & $151(100)$ & $32(100)$ & 107 (100) \\
\hline \multicolumn{10}{|l|}{ Policy } \\
\hline Research & $2(10)$ & 7 (17) & $2(17)$ & $32(52)$ & $4(57)$ & $4(40)$ & $32(48)$ & $2(18)$ & $43(48)$ \\
\hline Extension & $19(90)$ & $33(83)$ & $10(83)$ & $29(48)$ & $3(43)$ & $6(60)$ & $34(52)$ & $9(82)$ & $46(52)$ \\
\hline Total & $21(100)$ & $40(100)$ & $12(100)$ & $61(100)$ & $7(100)$ & $10(100)$ & 66 (100) & $11(100)$ & 89 (100) \\
\hline \multicolumn{10}{|c|}{ Resource and land mgmt } \\
\hline Research & $39(39)$ & $77(31)$ & $22(49)$ & $92(63)$ & $10(42)$ & $44(52)$ & $134(53)$ & $56(43)$ & $59(42)$ \\
\hline Extension & $62(61)$ & $170(69)$ & $23(51)$ & $55(37)$ & $14(58)$ & $40(48)$ & $121(47)$ & $73(57)$ & $80(58)$ \\
\hline Total & $101(100)$ & $247(100)$ & $45(100)$ & $147(100)$ & $24(100)$ & $84(100)$ & $255(100)$ & $129(100)$ & $139(100)$ \\
\hline \multicolumn{10}{|l|}{ Socioeconomic } \\
\hline Research & $6(20)$ & $8(15)$ & $2(22)$ & $30(47)$ & $7(54)$ & $11(42)$ & $39(47)$ & $5(28)$ & $48(49)$ \\
\hline Extension & $24(80)$ & $44(85)$ & $7(78)$ & $32(53)$ & $6(46)$ & $15(58)$ & $44(53)$ & $13(72)$ & $50(51)$ \\
\hline Total & $30(100)$ & $52(100)$ & $9(100)$ & $62(100)$ & $13(100)$ & $26(100)$ & $83(100)$ & $18(100)$ & $98(100)$ \\
\hline
\end{tabular}

*Numbers in parentheses represent percentages. 
Table 3. Frequency and percentage of respondents working climate change mitigation activities according to focus areas.

\begin{tabular}{|c|c|c|c|c|c|c|c|c|c|}
\hline \multirow[b]{2}{*}{$\begin{array}{l}\text { Climate Change } \\
\text { Adaptation }\end{array}$} & \multicolumn{9}{|c|}{$\begin{array}{c}\text { Focus areas* } \\
\mathrm{N}(\%)\end{array}$} \\
\hline & Animals & $\begin{array}{l}\text { Cropping } \\
\text { Systems }\end{array}$ & Engineering & Environment & $\begin{array}{l}\text { Food Science } \\
\text { and Nutrition }\end{array}$ & Forestry & $\begin{array}{c}\text { Natural } \\
\text { Resources }\end{array}$ & Plants & $\begin{array}{c}\text { Social } \\
\text { Sciences }\end{array}$ \\
\hline \multicolumn{10}{|l|}{ Energy } \\
\hline Research & $16(36)$ & $30(33)$ & $28(61)$ & $35(65)$ & $7(44)$ & $13(39)$ & $47(48)$ & $25(49)$ & $38(47)$ \\
\hline Extension & $29(64)$ & $62(67)$ & $18(39)$ & $19(35)$ & $9(56)$ & $20(61)$ & $43(52)$ & $26(51)$ & $43(53)$ \\
\hline Total & $45(100)$ & $92(100)$ & $46(100)$ & $54(100)$ & $16(100)$ & $33(100)$ & $90(100)$ & $51(100)$ & $81(100)$ \\
\hline \multicolumn{10}{|c|}{ Farm management } \\
\hline Research & $43(38)$ & $95(37)$ & $22(55)$ & $48(63)$ & $16(57)$ & $16(47)$ & $68(54)$ & $62(47)$ & $33(41)$ \\
\hline Extension & $71(62)$ & $163(63)$ & $18(45)$ & $28(37)$ & $12(43)$ & $18(53)$ & $58(46)$ & $71(53)$ & $48(59)$ \\
\hline Total & $114(100)$ & $258(100)$ & $40(100)$ & $76(100)$ & $28(100)$ & $34(100)$ & $126(100)$ & $133(100)$ & $81(100)$ \\
\hline \multicolumn{10}{|l|}{ Forestry } \\
\hline Research & $9(60)$ & $13(22)$ & $4(36)$ & $21(54)$ & $1(100)$ & $28(48)$ & $26(45)$ & $8(38)$ & $18(46)$ \\
\hline Extension & $6(40)$ & $46(78)$ & $7(64)$ & $18(46)$ & $0(0)$ & $31(52)$ & $32(55)$ & $13(62)$ & $21(54)$ \\
\hline Total & $15(100)$ & $59(100)$ & $11(100)$ & $39(100)$ & $1(100)$ & $59(100)$ & $58(100)$ & $21(100)$ & $39(100)$ \\
\hline \multicolumn{10}{|l|}{ Greenhouse gas } \\
\hline Research & $12(44)$ & $36(46)$ & $14(64)$ & $47(66)$ & $4(50)$ & $28(62)$ & $51(62)$ & $15(47)$ & $24(57)$ \\
\hline Extension & $15(56)$ & $43(54)$ & $8(36)$ & $24(34)$ & $4(50)$ & $17(38)$ & $31(38)$ & $17(53)$ & $18(43)$ \\
\hline Total & $27(100)$ & 79 (100) & $22(100)$ & $71(100)$ & $8(100)$ & $45(100)$ & $82(100)$ & $32(100)$ & $42(100)$ \\
\hline \multicolumn{10}{|c|}{ Policy and planning } \\
\hline Research & $12(28)$ & $6(9)$ & $6(35)$ & $52(60)$ & $4(40)$ & $6(25)$ & $64(51)$ & $4(15)$ & $55(52)$ \\
\hline Extension & $32(72)$ & $58(91)$ & $11(65)$ & $35(40)$ & $6(60)$ & $18(75)$ & $63(49)$ & $22(85)$ & $51(48)$ \\
\hline Total & $44(100)$ & $64(100)$ & $17(100)$ & $87(100)$ & $10(100)$ & $24(100)$ & $127(100)$ & $26(100)$ & $106(100)$ \\
\hline \multicolumn{10}{|l|}{ Socioeconomic } \\
\hline Research & $15(20)$ & $26(16)$ & $9(36)$ & $41(45)$ & $10(37)$ & $15(28)$ & $59(36)$ & $22(27)$ & $60(41)$ \\
\hline Extension & $60(80)$ & $137(84)$ & $16(64)$ & $50(55)$ & $17(63)$ & $38(72)$ & $103(64)$ & $59(73)$ & $88(59)$ \\
\hline Total & $75(100)$ & $163(100)$ & $25(100)$ & $91(100)$ & $27(100)$ & $53(100)$ & $162(100)$ & $81(100)$ & $148(100)$ \\
\hline
\end{tabular}

*Numbers in parentheses represent percentage 